\title{
Lessons for climate change adaptation from better management of rivers
}

\author{
JAMIE PITTOCK* \\ Fenner School of Environment \& Society, Australian National University, Canberra ACT 0200, Australia
}

\begin{abstract}
Autonomous adaptation in the water sector is assessed to derive lessons for more successful climate change adaptation from six empirical, consistently designed river management case studies based on projects of WWF. They show that when adaptation measures are considered in the context of common problems in water management, many practical ways of building resilience to climate change through mainstream programs are evident. The cases are mainly from developing countries - India, China, Mexico, Brazil, the lower Danube basin and Tanzania - where efforts to reduce environmental degradation and enhance livelihoods have directly helped to reduce vulnerability to natural hazards and climate change. The key lessons include: the benefits of concurrent measures for improving livelihoods and reducing physical vulnerability; the need to enhance and fund local institutions to mainstream adaptation programmes; and the value in implementing 'no and low regrets' measures despite uncertainties.
\end{abstract}

Keywords: adaptation; climate change; developing countries; institutions; non-governmental organizations; rivers; water

\section{Introduction}

The world faces grave challenges in sustaining water resources for people and nature, problems that are exacerbated by the impacts of climate change and the need for ongoing, effective and efficient adaptation. The term adaptation can be broadly applied to actions to manage changes in the environment or society, beyond impacts induced by climate change. The Intergovernmental Panel on Climate Change (IPCC) declares (Kundzewicz et al., 2007, p. 196) that: 'Adaptation to changing conditions in water availability and demand has always been at the core of water management'. The IPCC also defines autonomous adaptation actions as (Bates et al., 2008, p. 48): 'those that do not constitute a conscious response to climate stimuli, but result from changes to meet altered demands, objectives and expectations which, whilst not deliberately designed to cope with climate change, may lessen the consequences of that change.
Such adaptations are widespread in the water sector, although with varying degrees of effectiveness in coping with climate change'. As autonomous adaptations are widespread and possibly the most common form of adaptation to climate change, there is much that society can learn from the factors hindering and facilitating the effectiveness of such measures, and this is the focus of this paper. Further, as the climate will continue to change, adaptation is considered in this paper to be an ongoing rather than finite process (Matthews and Wickel, 2009).

To contribute to the design of more effective freshwater climate adaptation processes, this paper considers freshwater case studies that meet the IPCC's definition of autonomous adaptation to derive lessons on what motivated these societies to change, the factors that led to more successful processes, and how interventions may best be sustained. Rather than a theoretical assessment of what measures could or should be 
implemented, this paper seeks lessons from ongoing freshwater adaptation processes. The paper also considers the benefits of these autonomous adaptation measures in terms of how they increase resilience ${ }^{1}$ (Bates et al., 2008), and reduce vulnerability ${ }^{2}$ (Bates et al., 2008).

In many cases climate change is expected to be felt first, and most severely, by changes in hydrology. In response, development of effective policies requires in part 'practical implementation knowledge' as one key evidence base (Head, 2008), as well as scientific and political knowledge. While these case studies have elements of all three types of knowledge, it is lessons from ongoing implementation that are sought in this paper. Rather than a search for a complete package of programme elements (Dovers, 2005), the comparative policy analysis undertaken in this research is focused on subprogramme detail, derivation of lessons from specific elements of the processes, and also the policy style.

In 2008, in presenting the preliminary findings for UN Water's 3rd World Water Development Report, the report's content coordinator, Dr William J. Cosgrove, regretted the lack of published case studies that linked freshwater management and its potential to contribute to climate change adaptation. He called on implementing agencies to publish assessments of their activities. In response, this paper is intended to identify such knowledge from the work of a large non-governmental organization.

This paper reports on the global lessons drawn from six empirical, consistently designed case studies of autonomous freshwater adaptation processes based on projects of a conservation organization, the World Wide Fund for Nature (also known as the World Wildlife Fund or WWF). The cases are from India (Gujja et al., 2009), China (Yu et al., 2009), Mexico (Barrios et al., 2009), Brazil (Pereira et al., 2009), the lower Danube basin (Ebert et al., 2009) and Tanzania (Kashaigili et al., 2009). Project sites were selected by the largely independent local WWF offices at different times, although three of the six projects were substantially funded in the period reported on here through a globally coordinated programme called Investing in Nature, supported by the Hong Kong Shanghai Banking Corporation (HSBC) and WWF UK. The six river basins concerned were all considered by WWF to be significant for biodiversity conservation, and their conservation work commenced more than six years ago at all sites, except with the Godavari project. Otherwise, the only common thread in their selection was a need perceived by WWF and sectors of the local community to respond to severe environmental degradation, often indicated by disasters, which threatened biodiversity and peoples' livelihoods (Table 1).

In response to this environmental degradation, WWF and the local institutions instigated actions that reduce vulnerability to climate variability and related natural resource management problems, including the types of climate impacts expected to be exacerbated by climate change. WWF is a proponent of the sustainable development environmental discourse (Dryzek, 1997), and its actions in these field projects reflect their beliefs in nested social and ecological systems, that environmental protection and socioeconomic benefits are mutually reinforcing, and in decentralized, exploratory and variable approaches in pursuit of sustainability (Lee, 1993).

A key dilemma facing policymakers is whether adaptation is better facilitated by focusing on biophysical risk reduction, or whether it would be more effective to invest in reducing poverty and improving livelihoods more generally so as to build the resilience and adaptability of local communities to climate change impacts (Brooks, 2003; Adger, 2006; Schipper, 2007). The research considers how such measures are best integrated into society (Ross and Dovers, 2008). A further choice is between more technical infrastructure on the one hand, and on the other, favouring small-scale and decentralized interventions with a greater emphasis on increasing societal capacities (Moench and Stapleton, 2007; Ribot et al., 2009). These questions are further assessed in this paper. 
TABLE 1 Environmental degradation and disasters that instigated WWF and societal responses

\begin{tabular}{|c|c|c|c|}
\hline Basin and location & $\begin{array}{l}\text { Major environmental degradation and } \\
\text { disasters }\end{array}$ & $\begin{array}{l}\text { WWF project } \\
\text { period }\end{array}$ & $\begin{array}{l}\text { WWF project objective/s (as summarized } \\
\text { by the author) }\end{array}$ \\
\hline $\begin{array}{l}\text { Maner River tributary } \\
\text { of the Godavari River, } \\
\text { India }\end{array}$ & $\begin{array}{l}\text { Water scarcity - an increasing problem in } \\
\text { the region as populations increase and } \\
\text { water resources are extensively exploited. } \\
\text { Access to water is a focus of many } \\
\text { government and community organizations' } \\
\text { programmes. }\end{array}$ & $\begin{array}{l}\text { March 2005- } \\
\text { February } \\
2007\end{array}$ & $\begin{array}{l}\text { Assess the socio-economic and } \\
\text { environmental costs and benefits of } \\
\text { restoring traditional village water tanks } \\
\text { as an alternative to major infrastructure } \\
\text { schemes to increase water supplies. }\end{array}$ \\
\hline $\begin{array}{l}\text { Lakes in the central } \\
\text { Yangtze River basin, } \\
\text { China }\end{array}$ & $\begin{array}{l}\text { Floods, drought, pollution, fishery decline - } \\
\text { all increasing problems. Major floods in } \\
\text { 1995, 1996, } 1998 \text { and } 1999 \text { sparked } \\
\text { responses from governments. }\end{array}$ & $\begin{array}{l}2002 \text { to } \\
\text { present }\end{array}$ & $\begin{array}{l}\text { Demonstrate that re-linking floodplain lakes } \\
\text { to the Yangtze River, and promoting more } \\
\text { diverse and flood-adapted livelihood } \\
\text { activities would improve water quality, } \\
\text { biodiversity conservation and the } \\
\text { livelihoods of local people. }\end{array}$ \\
\hline Rio Conchos, Mexico & $\begin{array}{l}\text { Water scarcity - drought from } 1994 \text { to } 2006 \\
\text { instigated responses from stakeholders. }\end{array}$ & $\begin{array}{l}2002 \text { to } \\
\text { present }\end{array}$ & $\begin{array}{l}\text { Improve the condition of freshwater } \\
\text { ecosystems in the Rio Grande/Bravo basin } \\
\text { by promoting the application of integrated } \\
\text { river basin management. }\end{array}$ \\
\hline $\begin{array}{l}\text { Rio São João (Rio de } \\
\text { Janeiro State), Brazil }\end{array}$ & $\begin{array}{l}\text { Pollution, fishery decline, water scarcity. By } \\
1999 \text { eutrophication of water bodies had } \\
\text { largely eliminated the inland fisheries, and } \\
\text { reduced water access and sparked } \\
\text { community demands for rectification. }\end{array}$ & $\begin{array}{l}1999 \text { to } \\
\text { present }\end{array}$ & $\begin{array}{l}\text { Restore the water quality and biodiversity } \\
\text { of water bodies in the São João region by } \\
\text { promoting the application of integrated river } \\
\text { basin management. }\end{array}$ \\
\hline $\begin{array}{l}\text { Lower Danube River, } \\
\text { Romania, Bulgaria, } \\
\text { Moldova and the } \\
\text { Ukraine }\end{array}$ & $\begin{array}{l}\text { Floods, pollution both increasing problems. } \\
\text { Major floods in 1998-2002, } 2005 \text { and } 2006 \\
\text { resulted in demands for more effective } \\
\text { management by governments and } \\
\text { communities. }\end{array}$ & $\begin{array}{l}1992 \text { to } \\
\text { present }\end{array}$ & $\begin{array}{l}\text { Establishment of the Danube River basin } \\
\text { as a model of nature conservation and } \\
\text { community prosperity, including restoration } \\
\text { of freshwater and forestry resources along } \\
\text { the lower Danube. }\end{array}$ \\
\hline $\begin{array}{l}\text { Great Ruaha River, } \\
\text { Tanzania }\end{array}$ & $\begin{array}{l}\text { Water scarcity - river ceased flowing in the } \\
\text { dry season from } 1993 \text { resulting in a } 2001 \\
\text { Prime Ministerial commitment to restore } \\
\text { river flows. }\end{array}$ & $\begin{array}{l}2003 \text { to } \\
\text { present }\end{array}$ & $\begin{array}{l}\text { To enable the people of the Great Ruaha } \\
\text { River catchment to plan, manage and utilize } \\
\text { their water and related natural resources } \\
\text { sustainably, and by doing this, alleviate } \\
\text { poverty and improve livelihoods. }\end{array}$ \\
\hline
\end{tabular}

\section{Methods}

Six existing WWF projects (see Table 1) were selected for research by the author in consultation with staff of WWF UK. The projects were selected on the basis that they had the following characteristics: a significant focus on people's management of hydrological variability; were from countries with developing or emerging economies and from a broad continental distribution; and had been under way for sufficient time to have produced substantial outputs.

This assessment was undertaken between February and December 2008. Each WWF project was funded to employ a local consultant reporting to the local WWF office to prepare a case study report responding to an analytical framework. The reports covered the background to 
the work and the outputs and lessons in three areas: adaptation, livelihoods and conservation. They were prepared iteratively in consultation with the author in order to clarify data and increase consistency between the reports. The questions that were applied to each of the projects are detailed in the Annex. The case studies were then analysed by the author.

The work of these projects involved social and institutional changes as much as or more than biophysical and technological interventions. The measures deployed in these autonomous adaptation processes can be categorized as:

Decommissioning or changing the operations of underperforming infrastructure, like flood 'protection' dykes and sluice gates.

- Restoring the ability of the natural environment to provide ecosystem services, such as floodwater retention, storing water in aquifers, water purification and fisheries.

- Adopting locally available and small-scale technologies, such as village water tanks.

- Changing agricultural and aquacultural practices to more sustainable methods that: produce fewer pollutants; reuse water, such as for fish production then irrigation; are more water efficient; require less inputs; and secure higher returns for more valued produce.

n Providing better waste management systems, especially for sewerage.

- Diversifying local livelihoods into more profitable and less water-dependent enterprises.

- Increasing the incomes derived from natural commodities, such as fish, to reward producers adopting more sustainable practices and increase the resilience of these households.

- Establishing and strengthening local institutions to facilitate adaptive management and self-determination, including establishing and enforcing more sustainable behavioural norms for uses of natural resources such as water.

- Facilitating basin-scale multi-stakeholder institutions to: establish partnerships; develop common visions; lead adaptive management; and connect the local to global measures needed for more effective adaptation and sustainability.

- Advocating laws and government programmes that facilitate subsidiarity by providing basin and local institutions with the mandate and access to resources for adaptive management.

- Improving connectivity in freshwater ecosystems by applying environmental flows, ensuring wildlife passage through or over water infrastructure, and restoring riparian habitats.

- Restoring habitats to increase the resilience of these ecosystems to climate impacts, and their capacities to support greater populations of flora and fauna species, especially those that are threatened or of economic value.

\section{Results}

Table 2 summarizes the main adaptation, livelihood and conservation benefits to date from the six projects.

Successful outcomes to date from these autonomous adaptation cases can be categorized under the following:

Flood retention: increased capacity to safely retain higher peak flood flows.

- Water security: more reliable access to water in areas prone to scarcity.

- Pollution reduction: cuts to pollution levels and the risk that pollution impacts like eutrophication will be exacerbated by higher temperatures resulting from climate change.

- Livelihoods: diversified income generation strategies and increased incomes of many participants that may increase resilience of communities to climatic events.

- Institutional capacity: established and strengthened local institutions, increasing their adaptive management capacities.

- Connectivity: re-linked habitats and populations of species, enabling greater mobility and capacity to colonize new habitats that may be required to survive in a warmer world. 
TABLE 2 Summary of key climate adaptation, livelihood and conservation benefits

\begin{tabular}{|c|c|c|c|c|}
\hline Project & $\begin{array}{l}\text { Likely major } \\
\text { climate } \\
\text { change } \\
\text { impacts }\end{array}$ & Key climate adaptation benefits & $\begin{array}{l}\text { Key livelihood } \\
\text { benefits }\end{array}$ & Key ecosystem benefits \\
\hline \multirow{3}{*}{$\begin{array}{l}\text { Lower } \\
\text { Danube, } \\
\text { eastern } \\
\text { Europe }\end{array}$} & $\begin{array}{l}\text { Increased } \\
\text { flooding }\end{array}$ & $\begin{array}{l}\text { Flood storage increased through } \\
\text { restoration of floodplains. Plan to } \\
\text { restore } 2,250 \mathrm{~km}^{2} \text {. Of this area }\end{array}$ & Livelihoods diversified & $\begin{array}{l}\text { Restored } 4,430 \text { ha of habitats and } \\
\text { reconnected a } 68 \mathrm{~km}^{2} \text { lake to the } \\
\text { river }\end{array}$ \\
\hline & $\begin{array}{l}\text { Pollution } \\
\text { exacerbated }\end{array}$ & $14.4 \%$ has been or is being restored & $\begin{array}{l}\text { Better access to clean } \\
\text { water }\end{array}$ & Fish and bird populations restored \\
\hline & $\begin{array}{l}\text { Biodiversity } \\
\text { impacted }\end{array}$ & $\begin{array}{l}\text { Pollution and the risk of algal } \\
\text { blooms reduced }\end{array}$ & $\begin{array}{l}\text { Ecological services of } \\
\text { EUR500/ha from } \\
\text { restored floodplains }\end{array}$ & $\begin{array}{l}\text { Protected areas expanded by } \\
5,757 \mathrm{~km}^{2} \text {, including large areas } \\
\text { of floodplains, in Romania }\end{array}$ \\
\hline $\begin{array}{l}\text { Great } \\
\text { Ruaha } \\
\text { River, }\end{array}$ & $\begin{array}{l}\text { Greater } \\
\text { water } \\
\text { scarcity }\end{array}$ & Reduced vulnerability to drought & $\begin{array}{l}\text { Established } 20 \\
\text { Community Banks }\end{array}$ & Flows restored in some places \\
\hline Tanzania & $\begin{array}{l}\text { Biodiversity } \\
\text { impacted }\end{array}$ & $\begin{array}{l}\text { Water Users' Associations } \\
\text { and other basin institutions } \\
\text { strengthened }\end{array}$ & $\begin{array}{l}\text { Diversified into } \\
\text { livelihoods with } \\
\text { reduced reliance } \\
\text { on water }\end{array}$ & $\begin{array}{l}\text { Water sources and riparian } \\
\text { vegetation restored } \\
\text { Tree felling for charcoal production } \\
\text { reduced }\end{array}$ \\
\hline \multirow[t]{3}{*}{$\begin{array}{l}\text { Godavari } \\
\text { tanks, } \\
\text { India }\end{array}$} & $\begin{array}{l}\text { Greater } \\
\text { water } \\
\text { scarcity }\end{array}$ & $\begin{array}{l}\text { Greater surface and ground water } \\
\text { access from restored tanks }\end{array}$ & $\begin{array}{l}\text { Increased agricultural } \\
\text { production, } \\
\text { employment and } \\
\text { incomes }\end{array}$ & $\begin{array}{l}\text { Enhanced habitats for birds in the } \\
\text { tanks }\end{array}$ \\
\hline & $\begin{array}{l}\text { Impacts of } \\
\text { alternative } \\
\text { adaptation } \\
\text { options }\end{array}$ & $\begin{array}{l}\text { Tank management systems } \\
\text { established }\end{array}$ & $\begin{array}{l}\text { Reduced agricultural } \\
\text { inputs }\end{array}$ & $\begin{array}{l}\text { Alternative to environmental damage } \\
\text { from proposed new dam } \\
\text { demonstrated }\end{array}$ \\
\hline & & $\begin{array}{l}\text { Programme adopted by the state } \\
\text { government. Alternative to } \\
\text { proposed USD } \$ 4 \text { billion dam } \\
\text { demonstrated }\end{array}$ & Cultural benefits & \\
\hline $\begin{array}{l}\text { Yangtze } \\
\text { lakes, }\end{array}$ & $\begin{array}{l}\text { Flooding } \\
\text { increased }\end{array}$ & $\begin{array}{l}\text { Restored } 450 \mathrm{~km}^{2} \text { lakes. Can retain } \\
285 \mathrm{~mm}^{3} \text { of flood waters }\end{array}$ & $\begin{array}{l}\text { Improved access to } \\
\text { drinking water }\end{array}$ & $\begin{array}{l}\text { Restored } 450 \mathrm{~km}^{2} \text { lake habitats, new } \\
60 \mathrm{~km}^{2} \text { reserve }\end{array}$ \\
\hline China & $\begin{array}{l}\text { Pollution } \\
\text { exacerbated } \\
\text { Biodiversity } \\
\text { impacted }\end{array}$ & $\begin{array}{l}\text { Pollution and the risk of algal } \\
\text { blooms reduced } \\
\text { Government adopted restoration } \\
\text { policies }\end{array}$ & $\begin{array}{l}\text { Fish resources } \\
\text { increased } \\
\text { Diversification of } \\
\text { livelihoods and } \\
\text { increased incomes }\end{array}$ & $\begin{array}{l}\text { Populations of fish, birds and } \\
\text { Yangtze Porpoise increased }\end{array}$ \\
\hline & & $\begin{array}{l}\text { Yangtze Forum established for } \\
\text { adaptive management }\end{array}$ & & \\
\hline
\end{tabular}


TABLE 2 Continued

\begin{tabular}{|c|c|c|c|c|}
\hline Project & $\begin{array}{l}\text { Likely major } \\
\text { climate } \\
\text { change } \\
\text { impacts }\end{array}$ & Key climate adaptation benefits & $\begin{array}{l}\text { Key livelihood } \\
\text { benefits }\end{array}$ & Key ecosystem benefits \\
\hline \multirow[t]{3}{*}{$\begin{array}{l}\text { Rio } \\
\text { Conchos, } \\
\text { Mexico }\end{array}$} & $\begin{array}{l}\text { Greater } \\
\text { water } \\
\text { scarcity }\end{array}$ & Vulnerability to drought reduced & $\begin{array}{l}\text { More secure access } \\
\text { to water }\end{array}$ & Conservation of endemic fish \\
\hline & $\begin{array}{l}\text { Biodiversity } \\
\text { impacted }\end{array}$ & $\begin{array}{l}\text { Established institution for adaptive } \\
\text { basin management }\end{array}$ & $\begin{array}{l}\text { Increased economic } \\
\text { efficiency in } \\
\text { agriculture }\end{array}$ & $\begin{array}{l}\text { Developing payment for ecological } \\
\text { services and environmental flows }\end{array}$ \\
\hline & & $\begin{array}{l}\text { Environment recognized as a user } \\
\text { in the water law }\end{array}$ & $\begin{array}{l}\text { Enhanced livelihoods } \\
\text { of communities in the } \\
\text { headwaters }\end{array}$ & \\
\hline \multirow[t]{2}{*}{$\begin{array}{l}\text { Rio São } \\
\text { João, } \\
\text { Brazil }\end{array}$} & $\begin{array}{l}\text { Pollution } \\
\text { exacerbated }\end{array}$ & $\begin{array}{l}\text { Pollution cut by } 75 \% \text {, reducing } \\
\text { algal blooms }\end{array}$ & $\begin{array}{l}\text { Restored } 244 \mathrm{~km}^{2} \\
\text { coastal lagoons, } \\
\text { rejuvenating tourism } \\
\text { and fishing industries }\end{array}$ & $\begin{array}{l}\text { Restored riparian, floodplain and } \\
\text { lagoon habitats. Riparian corridors } \\
\text { link remnant habitat of a threatened } \\
\text { primate, the Golden Lion Tamarin }\end{array}$ \\
\hline & $\begin{array}{l}\text { Biodiversity } \\
\text { impacted }\end{array}$ & $\begin{array}{l}\text { Establishment of multi-stakeholder, } \\
\text { adaptive, river basin management } \\
\text { institutions } \\
\text { Management approach adopted } \\
\text { widely in other basins }\end{array}$ & $\begin{array}{l}\text { Training and } \\
\text { economic } \\
\text { diversification } \\
\text { Improved water } \\
\text { supply }\end{array}$ & $\begin{array}{l}\text { River connectivity restoration } \\
\text { planned }\end{array}$ \\
\hline
\end{tabular}

Populations and habitats: restored populations of species and areas of habitat that may be better able to resist and survive impacts of severe climatic events.

\section{Discussion}

Reviewing the outputs from these six case studies, the following eight overarching lessons for more effective adaptation processes are identified and listed in Table 3, together with the most relevant examples.

Considering these cases and lessons further, the following issues for effective adaptation are identified for wider discussion:

\subsection{Quantifiable targets}

Like many organizations, WWF continually debates whether more targeted and sophisticated programmes would achieve more benefits for people and the environment. In these case studies, there is little doubt that more climate-informed and target-driven projects could achieve more effective interventions. For example, environmental flow methods are being applied globally to better define the objectives of freshwater biodiversity conservation and the thresholds for the quantity and quality of water required to achieve them under the assumption of a stationary, natural hydrological regime. These methods could be applied to maintain specific freshwater biodiversity values under conditions of climate change (Anon., 2007). In the Ruaha and Rio Conchos projects, the generic interventions to attenuate water scarcity are buying both time and stakeholder ownership of the development of scientifically based, quantitative environmental flows. This suggests that taking action to adapt to the most obvious problems should not wait for more precise information. By 
TABLE 3 Lessons derived from the six case studies

Lesson derived

1. Local ownership. Participation of local stakeholders increased the sustainability and effectiveness of the measures.
2. Immediate benefits. Local stakeholder support depends on receipt of immediate benefits; these appeared to engender support for more challenging measures.

3. Multiple benefits. Many freshwater adaptations to climate change impacts are practical now, can be scaled up, and had multiple environmental and socio-economic benefits.

\section{Supporting examples}

Ruaha: Community ownership through Water Users' Associations has been essential to agree, implement and enforce measures beyond the government's reach; Godavari: Villagers contributed two-thirds of the resources needed for tank restoration and established local management institutions:

Rio Conchos: The Inter-institutional Working Group and work with irrigators and villagers in the river's headwaters have sustained major interventions;

Rio São João: Establishment of the basin Consortium, including local governments, has engaged wide sections of the community and driven reforms to water management.

Ruaha: Establishment of Community Conservation Banks and other livelihood benefits has underpinned support for environmental flow assessments; Yangtze: Enhanced livelihoods at initial sites has seen support for restoration of additional floodplain lakes;

Rio Conchos: Initial benefits from more

efficient water use have enabled consideration of environmental flow allocations:

Rio São João: Achievement of initial plans for reduced pollution and restored fisheries has led to plans for new measures to restore riparian corridors and the watershed.

Danube: Floodplain restoration offers immediate benefits and could be incrementally scaled up to manage increased flood risks;

Ruaha: Watershed restoration activities in half the districts in the basin delivered benefits, including increased river flows, and could be expanded to other districts;
Qualifying examples

Danube: To some extent the national and international demand for better flood control has prevailed in place of local community ownership of restoration of the Danube floodplains, but the absence of local consent has delayed progress at a number of sites; Yangtze: While local people and national authorities both owned restoration of the floodplain lakes for improved environmental quality and livelihoods, local institutions do not appear to support the use of these lakes by national authorities for flood management purposes. 
TABLE 3 Continued

\begin{tabular}{|c|c|c|}
\hline Lesson derived & Supporting examples & Qualifying examples \\
\hline & $\begin{array}{l}\text { Godavari: Village tank restoration is a cheap } \\
\text { option for increasing water supply and could } \\
\text { be expanded to cover more than } 200,000 \\
\text { such tanks in India; } \\
\text { Yangtze: Restoration of } 200 \mathrm{~km}^{2} \text { floodplain } \\
\text { lakes enhanced livelihoods, environmental } \\
\text { quality and flood control, and could be } \\
\text { expanded to a much larger floodplain area; } \\
\text { Rio Conchos: Watershed restoration and } \\
\text { water efficiency measures have } \\
\text { succeeded locally in reducing vulnerability } \\
\text { to drought and could be scaled up } \\
\text { considerably; } \\
\text { Rio São João: The institutions established for } \\
\text { water pollution reduction have succeeded on } \\
\text { this problem and are now moving } \\
\text { progressively to address other adaptation } \\
\text { challenges in water and basin } \\
\text { management. }\end{array}$ & \\
\hline $\begin{array}{l}\text { 4. Linking local to national to global. The most } \\
\text { effective measures drew strength and linked } \\
\text { institutions and action at different geopolitical } \\
\text { scales. }\end{array}$ & $\begin{array}{l}\text { Danube: Obligations under the European } \\
\text { Union and Danube Convention, national } \\
\text { policies and local action have combined } \\
\text { to initiate, fund and implement floodplain } \\
\text { restoration; } \\
\text { Yangtze: National policies for flood control } \\
\text { and more sustainable water management } \\
\text { enabled provincial and local government } \\
\text { authorities to implement the floodplain lake } \\
\text { restoration measures; } \\
\text { Rio Conchos: Obligations under the border } \\
\text { rivers treaty to deliver water to the USA } \\
\text { and funding from the North American } \\
\text { Development Bank, combined with the need } \\
\text { within Mexico to reduce vulnerability to } \\
\text { drought, resulted in effective water efficiency } \\
\text { measures; } \\
\text { Rio São João: National and state water laws } \\
\text { provided the mandate for the basin } \\
\text { Consortium and underwrote its funding, which } \\
\text { enabled local institutions to implement } \\
\text { reforms more effectively. }\end{array}$ & $\begin{array}{l}\text { Godavari: The case study of } \\
\text { restoration of } 12 \text { village tanks } \\
\text { involved relatively local-scale } \\
\text { actions. Yet this case relied on } \\
\text { international funding in a situation } \\
\text { where state and national } \\
\text { institutions had been ineffective } \\
\text { in facilitating action. Scaling up } \\
\text { application of tank restoration } \\
\text { would require state and possibly } \\
\text { national government support to } \\
\text { succeed. }\end{array}$ \\
\hline
\end{tabular}


TABLE 3 Continued

Lesson derived
5. Adaptive management. Effective
adaptation was an iterative process over
many years.

6. Funding adaptation. Regular funding was needed to sustain adaptation.

7. Communicating adaptation. The language and perception of adaptation as new and complicated appeared to have stymied engagement of local communities and governments.

\section{Supporting examples}

Danube: Sequential adoption of stronger basin agreements, from the Danube Convention in 1994, Lower Danube Green Corridor Agreement in 2000 and the EU Water Framework Directive milestones from 2000 to 2015 have provided renewed impetus for adaptive management;

Rio São João: Since its establishment in 1999 the basin Consortium has implemented three phases of measures, and as the preceding targets have been met, this has generated support for new interventions;

Ruaha: To a lesser extent the sequence of national policies since 1991 and water projects in this basin are also an example of iterative processes enhancing awareness of the issues and options for responses over time.

Godavari: Village institutions will collect water use fees to sustain management of restored tanks;

Rio São João: The Consortium was funded through fees from municipal government members and local companies. As well, the head of the Consortium is seconded from the state government. These resources are used to leverage additional funding for management measures.

Godavari, Yangtze and Rio São João: When first discussed with programme leaders they expressed the view that the contradictory and uncertain scenarios from climate impact models for these places meant that it was not possible to define climate change adaptation measures yet. Additional views expressed included: different opinions of Chinese academic and government officials on the nature of climate change; the need for vulnerability assessments to precede adaptation measures; the lack of locally
Qualifying examples

Godavari: The case study interventions appear sustainable after just 2 years. Yet this involved relatively local-scale actions applying one technology. It is likely that an iterative approach would be required to incrementally improve local benefits, such as through tank watershed conservation, or to scale up tank restoration through larger programmes at the state or national scales.

Ruaha: Although promised in the national water policy the allocation of water use fees back to local management institutions has not occurred, jeopardizing the ongoing work of these organizations;

Rio Conchos: State law frustrates efforts to establish binding payment for a watershed services scheme, which would enable urban dwellers to cross-subsidize watershed management and restoration measures.

Danube: The large floods in the past decade appeared to have helped key institutions in the basin agree on the need for floodplain restoration and a key measure to manage the impacts of more frequent flooding due to climate change; 


\begin{tabular}{|c|c|c|}
\hline Lesson derived & Supporting examples & Qualifying examples \\
\hline & $\begin{array}{l}\text { available experts to advise on desirable } \\
\text { measures; and the urgency of reducing } \\
\text { existing threats to sustainable water } \\
\text { management before engaging the } \\
\text { longer-term impacts of climate change. }\end{array}$ & $\begin{array}{l}\text { Rio Conchos: Project leaders } \\
\text { appear to have considered that } \\
\text { the } 1994-2006 \text { drought may } \\
\text { represent the sort of climate } \\
\text { change impact to which their } \\
\text { society would need to adapt. }\end{array}$ \\
\hline $\begin{array}{l}\text { 8. Post-disaster reform windows. Adaptation } \\
\text { only followed major disasters or severe } \\
\text { environmental degradation. }\end{array}$ & All six projects demonstrate this (see Table 1). & - \\
\hline
\end{tabular}

contrast, in the Yangtze and Danube, the floodwater retention capacities achieved by the restoration of floodplain sites are known and appear to be part of larger governmental decisions on the levels of acceptable flood risk.

\subsection{Thresholds of climate impacts}

Another key question is whether the resilience building measures implemented in these projects would be overwhelmed as climate change impacts exceed key thresholds. For instance, if climate change impacts become much more severe there is a risk that the responses to manage water scarcity and quality documented in these projects, successful to date, could be insufficient to meet the future water needs of people and the environment. Yet these resilience-building measures have engaged and enhanced the capacities of local institutions in adaptive management processes (such as with the Water User Associations and the Community Conservation Banks in the Great Ruaha) that may provide the social and institutional resources needed to respond to greater climate impacts. These actions to date have bought time to consider whether more radical measures are required. A recent assessment of the Ruaha basin was undertaken and has concluded that the improved catchment management measures (while highly beneficial in increasing river flows and reducing vulnerability of local communities to water scarcity in the upper basin) would not exceed the threshold needed to provide water flow through a major wetland and further downstream in the central basin in the dry season. Consequently the diversion of an upstream tributary, the Ndembera River, around the Usangu wetland has been proposed to provide a base flow to the main stem of the river (Mwaruvanda et al., 2009). Yet nearly all of the actions described in these case studies have two prized qualities: they are 'no or low regrets' measures, for instance, in increasing flood retention capacity, and they can be scaled up considerably to substantially increase resilience at a basin or even greater scales, such as by restoring more of the estimated 208,000 village tanks in India.

These case studies also illustrate the need to seize the impetus for adaptation following major disasters or severe environmental degradation (Adger et al., 2005, p. 85).

\subsection{Motivation and adaptive behaviours}

While WWF and local institutions did not initially conceive any of these projects as comprehensive climate change adaptation, the degree to which adaptation was considered varied between the projects. For example, the Danube project explicitly addressed floods as a climate change impact, while the Rio São João project had not thought of climate change until it was raised by this study. WWF is committed to promoting climate change adaptation measures globally 
and has provided guidance to staff since at least 2003 (Hansen et al., 2003). The project staff of WWF and their local institutional partners include people highly educated in relevant fields, yet few had focused on climate change. Why had these local intellectual leaders not fully considered adaptation needs? What would mobilize more leaders and their societies to mainstream adaptation processes?

A response given by staff from three of the projects when approached to participate in this research was that insufficient climate change impact data was available for their river basin to enable development of targeted actions. Upon further discussion it appeared that there were two main reasons why planned climate adaptation work had not commenced in four of the six cases. There was a perception that measures could not commence until climate change models could supply more specific data on possible impacts, and a view that the required expertise and data was not available locally or nationally. In two cases project staff expressed the view that, because climate change projections included a range of contrasting potential outcomes in terms of rainfall and river inflows, interventions could be premature. In general, the option of identifying 'no and low regrets' adaptation measures had not been explicitly considered to manage risk and uncertainties. There was also a commonly held view (with some justification) that the current, non-climate threats to the sustainability of the river systems, such as excessive water diversions and pollution, were so large and fast-growing that they needed to be addressed first. Thus most of the project staff saw the climate change information available to them as lacking salience (Meinke et al., 2006).

Consequently, proponents of adaptation need to consider whether the sometimes obscure methods, jargon, data and expertise around climate adaptation are a barrier for many societies to implementation of appropriate measures; whether shifting from an information deficit to more participatory approaches would be more effective in changing behaviour (Burgess et al., 1998). As a result of participating in this research, the project staff responded with renewed confidence that the adaptation actions they are implementing can be enhanced and become better climate-informed. This suggests that there are many local institutions that - if directly engaged in locally relevant ways (Burgess et al., 1998; Meinke et al., 2006) - will consider climate change adaptation measures. It was also clear that many local people and institutions initially implemented these actions more for the short-term benefits for livelihood and development, and only later came to support the programmes for their benefits in reducing vulnerabilities to climatic variability and other environmental hazards. To succeed, proponents need to link climate adaptation to outcomes of value to local communities.

\subsection{Enhancing livelihoods vs. reducing risks}

In terms of whether adaptation outcomes are best achieved by focusing on social and biophysical risk reduction or by development to reduce poverty and enhance livelihoods (Adger, 2006; Schipper, 2007) compelling evidence emerges from these projects that a concurrent investment facilitates more effective change. All the projects had substantial components focused on enhancing livelihoods as well as other environmental measures, consistent with WWF's support for sustainable development. This is well illustrated by the Great Ruaha and Godavari case studies, where average incomes were just USD0.80 and USD1.34 per day, respectively. In the Great Ruaha, the establishment of Community Conservation Banks enabled diversification into less water-intensive and more profitable livelihoods concurrently with the establishment of Water User Associations to enhance local governance of water and reduce risks. In the Godavari basin, capital investment to reduce vulnerability to water scarcity by expanding village tanks was provided alongside the establishment of village tank management committees, the recruitment of local labourers to maintain the tanks, and enhancement of agricultural production and 
employment. The prospect of sustainable development also appears to have been vital in securing the support of local and provincial scales of government, notably in China.

\subsection{Centralized infrastructure vs. decentralized interventions}

These case studies also highlight the benefits of focusing on small-scale, decentralized adaptation measures and increasing societal capacities rather than investing in more technical infrastructure (Moench and Stapleton, 2007). In water management globally there is a pervasive bias towards investment in supply-side and centralized water infrastructure solutions (Molle, 2008). In the Godavari case, the WWF project suggests that restoring all the village tanks in the relatively small Maner River sub-basin at an estimated cost of USD635 million would provide a water storage capacity (1.764 billion $\mathrm{m}^{3}$ at $3 \mathrm{~m}$ depth) (Gujja et al., 2009) similar to the proposed USD4 billion Polavaram Dam on the Godavari River $\left(2.130\right.$ billion $\mathrm{m}^{3}$ ) (Gujja et al., 2006). While not strictly comparable, because the larger catchment of the dam may see it divert over 4 times more water $\left(8.130\right.$ billion $\mathrm{m}^{3}$ proposed) than the restored tanks, the cost of tank restoration appears cheaper than the proposed dam. Further, the dam would displace 250,000 people, inundate sites of environmental and cultural value, and supply a relatively constrained region. By contrast with the dam, restored village tanks would be more widely distributed to supply the poorest sections of society and enable local communities to manage their own water supplies. Similarly, in the cases of both the Danube and the Yangtze, the physical limits and costs of raising ever higher flood 'protection' dykes appear to be outweighed by the potential of greater safety, lower costs and multiple benefits derived from restoring floodplains.

\subsection{Mainstreaming adaptation processes}

Better methods for integrating adaptation processes into society are also suggested from the
WWF case studies which support Ross and Dovers' (2008) proposition that the 'most prominent success factors, barriers and gaps that effect environmental policy integration relate to leadership, long term embedding of environmental policy integration and implementation capacity'.

Charismatic local leadership and the establishment or strengthening of local or basinscale institutions appears vital from the six projects. Local institutions had a key role in establishing new social norms to effect the changes in behaviour needed to better manage water, especially in those societies where the reach of government is limited, as illustrated in the Tanzanian, Indian and Brazilian case studies. At the basin scale, in the most successful programmes - those in Brazil, Mexico and the Danube - multi-stakeholder river basin organizations had been established and showed signs of the systematic social learning promoted by Lee (2003). Their work plans had set mediumterm targets that, once achieved, had built confidence and facilitated a virtuous cycle of adaptive management through new iterations of basin plans similar to that described by Dovers (2005). In the case of São João, for instance, the São João Consórcio is implementing the third phase of their work, having achieved the pollution reduction and other targets of their first two plans.

In the best cases, a modest level of independent income appeared vital to the effectiveness of local institutions. In Brazil, the São João Consórcio secured a reliable income to underwrite a large part of their work from: (a) municipal government membership fees scaled according to the population of their jurisdictions, and (b) local company participation fees. In addition, the state government seconded a staff member to lead the secretariat of the consortium. By contrast, in Tanzania promises by the national government to allocate water user fees to local institutions had not been implemented, leaving these organizations dependent on aid funds. In Mexico, state law prevented the establishment of a 
scheme to provide compulsory payments for environmental services. The social, institutional and environment-focused interventions studied had a modest cost and were cheaper than either identified impacts or alternative options, such as the dam proposed in India. Upfront investment was required for necessary infrastructure, seed capital or loans, and to pay transition costs. The initial funding came from nongovernmental organizations, development banks and other aid donors. National governments often contributed funding only after the measures had shown the potential to succeed and, in some situations, were yet to implement promised reforms to guarantee funding for subnational institutions.

This research sought to collect data on the return on investment of the measures implemented and proposed from these projects. While this information is incomplete, an assessment is possible. In the lower Danube a flood in 2005 killed 34 people and caused EUR396 million (USD625 million) in damages, whereas restoration of a larger area of floodplains would cost an estimated EUR20 million based on WWF project experience and generate ecological services worth EUR50 million per year. In Tanzania, each of the Water User's Associations cost USD13-27,000 to establish, and each Community Conservation Bank required an initial loan of USD4,000, compared to a national water budget of USD951 million from 2008 to 2011. The Maner sub-basin project to restore 12 village tanks serving 42,000 people cost WWF USD28,000 with USD75,000 contributed in kind by local people, and as indicated earlier, tank restoration appears more costeffective than the large dam proposed on the Godavari River. In the Rio Conchos, an initial expenditure of USD140 million was made to reduce irrigation surface water demand, and the Inter-institutional Working Group is investing USD3.2-4.4 million per year to manage the basin more sustainably. These examples demonstrate that investments in adaptations that reinforced institutional capacities and strengthened environmental resilience can be modest, may have a substantial return on investment, and may be cheaper than alternative large-scale infrastructure projects.

\subsection{Adaptation at different scales}

Adger et al. (2005) argue that the success of adaptation processes at different scales can be judged by whether they are: (a) effective (are robust in the face of uncertainty and flexible), (b) efficient (in terms of costs and benefits), (c) equitable, and (d) legitimate. The most effective processes seen in these case studies drew strength and linked action at different geopolitical scales. Subnational governments were enthusiastic partners in these programmes, apparently motivated by sustainable development opportunities and the need to reduce vulnerability to natural hazards. National laws and resource provision that support basin- and sub-basin-scale institutions appeared vital for adaptive management of freshwaters, and were a considerable barrier where they did not exist, or had perverse impacts. Basin and multilateral treaties were a catalyst for better river management in trans-boundary situations, although they could be considered inflexible in terms of their provisions in the event of climate change, for instance, in specifying particular water allocations. In the case of the Rio Conchos, Mexico's challenge in meeting its water delivery obligations to the USA ensured that considerable funding was available for river management reforms, that the state and national governments were supportive, and in future it may be possible to enhance environmental outcomes through smarter water delivery to the Rio Grande/Bravo. In the Danube basin the International Convention for the Protection of the Danube River, and the obligations of EU member states to implement the EU Water Framework Directive and related laws appeared to be a powerful driver for national law reform in Bulgaria and Romania. At different scales the measures adopted in the Danube are robust and flexible in terms of, for instance, capacity to increase flood water retention. In each of these case studies the interventions appeared efficient, 
with benefits outweighing alternatives, social equity was improved through enhanced livelihoods, and legitimacy was established through extensive local and multi-stakeholder participation.

\subsection{Responses from other practitioners}

The Yangtze and Ruaha case studies and the preliminary conclusions of this research were presented on 21 August 2008 at the Water and Climate Day 2, Adaptation in Practice session of the Stockholm World Water Week, along with the research of four others. Dr Guy Howard, for the UK Department for International Development (Anon., 2008) summarized the main messages related to this research for more effective adaptation from the presentations and participants' discussion. The importance of climatesmart local, regional and national water management institutions was recognized. Multiple benefits were identified from investment in ecosystems as adaptation measures because they can be cheap, scalable and will not limit future options. It was noted that successful examples of self-help strategies relied on visible and relatively immediate socio-economic returns. The benefits of learning by doing based on best current knowledge were observed, and the difficulty of upscaling and mainstreaming adaptation strategies were noted. It was concluded that funding predictability is just as important as the scale of funding for local institutions.

\section{Conclusions}

The six cases studied in this report show that, when adaptation measures are considered in the context of common problems in water management, many practical ways of building resilience to climate change through mainstream programmes are evident. Many freshwater interventions identified in these projects could be scaled up and had benefits for peoples' livelihoods and for nature conservation: they were 'no and low regrets' measures. Further lessons on sub-programme detail and policy styles derived from these case studies that could support successful adaptation programmes include the value of: local ownership; provision of some immediate benefits; linking local to global actions; applying adaptive management; consistently funding programmes; better explaining the opportunities for action; and seizing post-disaster policy response opportunities.

This research demonstrates that adaptation is best considered as a pathway that starts by implementing 'no and low regrets' measures to address obvious vulnerabilities that most societies could undertake with locally available knowledge and technologies. These small-scale measures can be scaled up, and they also buy time for thinking about and gathering the resources needed for solutions to more challenging problems, should they later emerge. A number of these case studies exhibit a virtuous cycle where initial, successful interventions have generated stakeholder support and built capacities for progressively more sophisticated measures that will further enhance adaptation to climate change. This pathway could be accelerated in many societies by investing in the development of expertise in technical skills and facilitating institutional development.

Freshwater resources and ecosystems are under great threat from non-climate-related pressures, and water managers are focused on finding solutions to these challenges. The daunting and global nature of climate change appears to have further dissuaded many leaders and institutions from engaging in climate change adaptations in many of the cases studied. A common perception that particular expertise, data and methods are needed appears to have stalled active consideration of the issue and opportunities.

This research supports Dovers' (2009) propositions that 'we can go at least halfway to a believable adaptation policy by implementing known, well-supported policy and management options' and by 'normalizing adaptation, and empowering officials, agencies, local communities'. 


\section{Acknowledgements}

Dr Kossa Rajabu from WWF Tanzania, who died in December 2008, contributed to this research. WWF staff and local consultants who prepared the case studies assessed in this paper include:

- Danube: Andreas Beckmann, David Strobel, Suzanne Ebert and Kimberly Chan.

- Ruaha: Japhet Kashaigili, Petro Masolwa and Kossa Rajabu.

- Godavari: Biksham Gujja, Sraban Dalai, Hajara Shaik and Vinod Goud.

- Yangtze: Xiubo Yu, Luguang Jiang, Jinxin Wang, Jiang Zhu, Gang Lei, Limin Wang and Lifeng Li.

- São João: Firmino Pereira, Samuel Barreto and Michael Volcker.

- Conchos: Venancio Trueba, Eugenio Barrios, Mauricio De la Maza Benignos and Alfredo Rodríguez.

This research was sponsored by HSBC Climate Partnership, and was supported by WWF UK, in particular: Dave Tickner, Philip Leonard, Tom Le Quesne and Mica Ruiz. Comments were gratefully received from Dr John Matthews, Dr Karen Hussey and Prof Stephen Dovers, and two reviewers. This research draws on the work of many WWF staff, partners and donors whose contributions are greatly appreciated.

\section{Notes}

1. Resilience has been defined as 'the ability of a social or ecological system to absorb disturbances while retaining the same basic structure and ways of functioning, the capacity for self organization, and the capacity to adapt to stress and change' (IPCC, 2007).

2. Vulnerability has been defined as the degree to which a system is susceptible to, and unable to cope with, adverse effects of climate change, including climate variability and extremes. Vulnerability is a function of the character, magnitude, and rate of climate change and variation to which a system is exposed, its sensitivity, and its adaptive capacity' (IPCC, 2001).

\section{References}

Adger, W. N., 2006. Vulnerability. Global Environmental Change, 16(3). 268-281.

Adger, W. N., Arnell, N. W. and Tompkins, E., 2005. Successful adaptation to climate change across scales. Global Environmental Change Part A, 15(2). 77-86.

Anon., 2007. The Brisbane Declaration. 10th International River Symposium and International Environmental Flows Conference. The Nature Conservancy, Brisbane, Australia.

Anon., 2008. 2008 Synthesis Report. Progress and Prospects on Water: For a Clean and Healthy World with Special Focus on Sanitation. World Water Week, 17-23 August 2008. Stockholm International Water Institute, Stockholm.

Barrios, J. E., Rodríguez-Pineda, J. A. and De la Maza, 2009. Integrated river basin management in the Conchos River basin, Mexico: a case study of freshwater climate change adaptation. Climate and Development, 1(3). 249-260. doi:10.3763/cdev.2009.0024.

Bates, B. C., Kundzewicz, Z. W., Wu, S. and Palutikof, J. P. (eds), 2008. Climate Change and Water. Technical Paper of the Intergovernmental Panel on Climate Change. IPCC Secretariat, Geneva.

Brooks, N., 2003. Vulnerability, Risk and Adaption: A Conceptual Framework. Tyndall Centre for Climate Change Research Working Paper 38. Tyndall Centre for Climate Change Research, Norwich, UK.

Burgess, J., Harrison, C. M. and Filius, P., 1998. Environmental communication and the cultural politics of environmental citizenship. Environment and Planning $A$, 30. 1445-1460.

Dovers, S., 2005. Environment and Sustainability Policy: Creation, Implementation, Evaluation. Federation Press, Annandale, VA.

Dovers, S., 2009. Normalizing adaptation. Global Environmental Change, 19(1). 4-6.

Dryzek, J. S., 1997. The Politics of the Earth: Environmental Discourses. Oxford University Press, Oxford and New York.

Ebert, S., Hulea, O. and Strobel, D., 2009. Floodplain restoration along the lower Danube: a climate change adaptation case study. Climate and Development, 1(3). 212-219. doi:10.3763/cdev.2009.0022.

Gujja, B., Ramakrishna, S., Goud, V. and Sivaramakrishna (eds), 2006. Perspectives on Polavaram: A Major Irrigation Project on the Godavari. Academic Foundation, New Delhi.

Gujja, B., Dalai, S., Shaik, H. and Goud, V., 2009. Adapting to climate change in the Godavari River basin of India by restoring traditional water storage systems. 
Climate and Development, 1(3). 229-240. doi:10.3763/ cdev.2009.0020.

Hansen, L. J., Hoffman, J. R. and Biringer, J. L., 2003. Buying Time: A User's Manual to Building Resistance and Resilience to Climate Change in Natural Systems. WWF, Gland, Switzerland.

Head, B. W., 2008. Three lenses of evidence-based policy. Australian Journal of Public Administration, 67(1). 1-11.

IPCC (Intergovernmental Panel on Climate Change), 2001. Climate Change 2001: Impacts, Adaptation, and Vulnerability: Contribution of Working Group II to the IPCC Third Assessment Report 2001, J. J. McCarthy, O. F. Canziani, N. A. Leary, D. J. Dokken and K. S. White (eds). Cambridge University Press, Cambridge, UK.

IPCC (Intergovernmental Panel on Climate Change), 2007. Climate Change 2007: Impacts, Adaptation and Vulnerability. Contribution of Working Group II to the Fourth Assessment Report of the Intergovernmental Panel on Climate Change. Appendix I: Glossary, M. L. Parry, O. F. Canziani, J. P. Palutikof, P. J. van der Linden and C. E. Hanson (eds). Cambridge University Press, Cambridge, UK. 869-883.

Kashaigili, J. J., Rajabu, K. and Masolwa, P., 2009. Freshwater management and climate change adaptation: experiences from the Great Ruaha River catchment in Tanzania. Climate and Development, 1(3). 220-228. doi:10.3763/cdev.2009.0025.

Kundzewicz, Z. W., Mata, L. J., Arnell, N. W., Döll, P., Kabat, P., Jiménez, B., Miller, K. A., Oki, T., Sen, Z. and Shiklomanov, I. A., 2007. Freshwater resources and their management. Climate Change 2007: Impacts, Adaptation and Vulnerability. Contribution of Working Group II to the Fourth Assessment Report of the Intergovernmental Panel on Climate Change, M. L. Parry, O. F. Canziani, J. P. Palutikof, P. J. van der Linden and and C. E. Hanson (eds). Cambridge University Press, Cambridge, UK. 173-210.

Lee, K. N., 1993. Compass and Gyroscope: Integrating Science and Politics for the Environment. Island Press, Washington, DC and Covelo, CA.

Matthews, J. H. and Wickel, A. J., 2009. Embracing uncertainty in freshwater climate change adaptation: a natural history approach. Climate and Development, 1(3). 269-279. doi:10.3763/cdev. 2009.0018.

Meinke, H., Nelson, R., Kokic, P., Stone, R., Selvaraju, R. and Baethgen, W., 2006. Actionable, climate knowledge: from analysis to synthesis. Climate Research, 33. 101-110.

Moench, M. and Stapleton, S., 2007. Water, Climate, Risk and Adaptation, Working Paper 2007/01. Cooperative Programme on Water and Climate, Delft, The Netherlands.
Molle, F., 2008. Why enough is never enough: the societal determinants of river basin closure. Water Resources Development, 24(2). 217-226.

Mwaruvanda, W., Kashaigili, J. J., O'Keeffe, J. H. and Von Der Heyden, C., 2009. Restoring flows in the Great Ruaha River, Tanzania. International Conference on Implementing Environmental Water Allocations. Port Elizabeth, South Africa.

Pereira, L. F. M., Barreto, S. and Pittock, J., 2009. Participatory river basin management in the São João River, Brazil: a basis for climate change adaptation? Climate and Development, 1. 1-8. doi:10.3763/cdev.2009.026.

Ribot, J. C., Najam, A. and Watson, G., 2009. Climate variation, vulnerability and sustainable development in the semi-arid tropics. The Earthscan Reader on Adaptation to Climate Change, E. L. F. Schipper and I. Burton (eds). Earthscan, London. 117-160.

Ross, A. and Dovers, S., 2008. Making the harder yards: environmental policy integration in Australia. Australian Journal of Public Administration, 67(3). 245-260.

Schipper, E. L. F., 2007. Climate Change Adaptation and Development: Exploring the Linkages. Tyndall Centre Working Paper No. 107. Tyndall Centre for Climate Change Research, Norwich, UK.

Yu, X., Jiang, L., Li, L., Wang, J., Wang, L., Lei, G. and Pittock, J., 2009. Freshwater management and climate change adaptation: experiences from the central Yangtze in China. Climate and Development, 1(3). 241-248. doi:10.3763/cdev.2009.0023.

\section{Annex: Analytical framework}

\section{A. Background and overview}

Place/river basin

Country

Why it is an example of climate change adaptation

Summary (of sections B-D):

Change in climate change resilience

Change in livelihoods

Change in conservation status

Key lessons

What worked

What did not work well 
Timeline of processes and WWF and partners' interventions

Quality of the data. If any of the questions below could not be answered, why not?

Main actors - their roles and relationships:

Government agencies: local/provincial or state/national/multilateral

- Business

- Community

- Multi-stakeholder

What intra- and inter-governmental processes were used?

What elements made interactions between these stakeholders positive or negative?

\section{B. Climate change adaptation}

1. What was the baseline situation?

2. What are the natural historic, climatic and hydrologic risks in the area?

3. How do local people cope with these risks traditionally?

4. What increased risks are forecast with climate change?

5. What are the project's climate change adaptation outcomes? Can these be quantified? To what extent are these based on having more resilient institutions?

6 . Were these planned or serendipitous?

7. Were these planned to address a future forecast threat (e.g. potentially larger floods or greater water scarcity) or were they intended to incrementally improve management of an existing problem (e.g. current flood levels or current water shortages)?

8. Is the improvement in climate change adaptation sustainable?

9. Why has the project been successful in improving climate change adaptation?

- What activities have been carried out at the macro, meso and micro scales?

- Which formal institutions were in place that have contributed to a favourable outcome?
Which informal institutions were in place that have contributed to a favourable outcome?

- What assumptions were made before the project was implemented and were these realistic?

- What was the time frame within which benefits could be measured?

- How were local people, their knowledge and needs integrated into the project?

- Which partnerships with stakeholders were established in the project and what roles did these play?

10. What should be done differently for similar projects in future?

11. Can the outcomes in the project site compare to a similar place that was not involved in the project?

12. What needs to be done to ramp up these adaptation techniques to the basin scale and what would it cost?

\section{Socio-economics}

1. What was the baseline situation?

2. What are the project's livelihood outcomes?
(a) More income?
(b) Increased well-being?
(c) Reduced vulnerability?
(d) More sustainable use of the natural resource base?

3. What is the distribution of socio-economic benefits?
(a) Gender?
(b) Age groups?
(c) Income groups?
(d) Disadvantaged groups (HIV/AIDS, unem- ployed, disabled, etc)?

4. What would have happened to people's livelihoods without the project?

5. Is the improvement in livelihoods sustainable?

6. Why has the project been successful in improving livelihoods?
What activities have been carried out at the macro, meso and micro scales? 
Which formal institutions were in place that have contributed to a favourable outcome?

- Which informal institutions were in place that have contributed to a favourable outcome?

- What assumptions were made before the project was implemented and were these realistic?

- What was the time frame within which benefits could be measured?

- How were local people, their knowledge and needs integrated into the project?

- Which partnerships with stakeholders were established in the project and what roles did these play?

7. What should be done differently for similar projects in future?

8. Can you compare the outcomes in the project site to a similar place that was not involved in the project?

9. What would be the socio-economic impacts of business-as-usual and what is the benefit of magnifying the project to the other relevant parts of the river/basin? Balance this with what it would cost to implement these adaptation techniques in the above section.

\section{Conservation}

1. What was the baseline situation?

2. What was the conservation objective/s of WWF's intervention/s?
3. What are the project's environmental outcomes?

4. Is the improvement in conservation sustainable?

5. Why has the project been successful in improving conservation?

- What activities have been carried out at the macro, meso and micro scales?

- Which formal institutions were in place that have contributed to a favourable outcome?

- Which informal institutions were in place that have contributed to a favourable outcome?

- What assumptions were made before the project was implemented and were these realistic?

- What was the time frame within which benefits could be measured?

- How were local people, their knowledge and needs integrated into the project?

- Which partnerships with stakeholders were established in the project and what roles did these play?

6. What should be done differently for similar projects in future?

7. Can you compare the outcomes in the project site to a similar place that was not involved in the project?

8. What would be the impact of business-asusual and the conservation/ecological benefits of ramping up to the river/basin scale? 